\title{
Transitional Justice measures implemented in Argentina: their psychosocial impact
}

\author{
Medidas de Justicia Transicional implementadas en Argentina, \\ su impacto psicosocial
}

\author{
Elena Zubieta \\ University of Buenos Aires \\ ezubieta@psi.uba.ar \\ Juan Bombelli \\ Argentine Catholic University \\ bombelli_juan_ignacio@hotmail.com \\ Marcela Muratori \\ University of Buenos Aires \\ marcelamuratori@hotmail.com
}

Citation/Cómo citar: Zubieta, Elena; Bombelli, Juan; Muratori, Marcela. 2021. "Transitional Justice measures implemented in Argentina: their psychosocial impact». Deusto Journal of Human Rights, No. 8: 19-49. doi: http://dx.doi.org/10.18543/djhr.2283.

Summary: 1. Collective Violence and Transitional Justice 2. Transitional Justice in Argentina. 3. Recognitions of crimes and public apologies. 4. Emotional social climate. 5. Method. 6. Participants. 7. Variables and instruments. 8. Data analysis. 9. Results. 10. Conclusions. References.

Abstract: Terrorism carried out by State forces is the most reprehensible action to be taken because the power and resources of a country are used to generate terror. Such power and resources are aimed at reaching certain political goals instead of serving the citizens. Transitional Justice has raised complex debates related to democratisation, human rights and the reconstruction of the State and its institutions after periods of severe social conflict. After the last military dictatorship in Argentina (1976-1983), different transitional justice mechanisms were implemented to cope with the consequences of the State's collective violence: Truth Commission, criminal trials, institutional reforms, as well as reparatory gestures. A descriptivecorrelational study of group difference was developed, with a non-experimental 
cross-sectional design. It was aimed at analysing the psychosocial impact of transitional justice measures taken in Argentina. The study was conducted on a non-probabilistic sample composed of 576 participants. Findings support the effectiveness of combined Transitional Justice measures, the weakness of recognition of criminal acts and apologies, and significant differences in terms of violence affectation.

Keywords: Argentine dictatorship, collective violence, transitional justice measures, psychosocial impact, violence affectation.

Resumen: El terrorismo de Estado es el más ignominioso porque los poderes y recursos de un país se utilizan para generar terror y obtener ciertos objetivos políticos en lugar de estar al servicio de la ciudadanía. La Justicia Transicional (JT) incluye debates sobre la democratización, los derechos humanos y la reconstrucción del Estado post períodos de extrema conflictividad social. Finalizada la dictadura militar (1976-1983) en Argentina, se implementaron mecanismos de JT para afrontar las consecuencias de la violencia colectiva estatal: Comisión de Verdad, procesos penales, reformas institucionales y gestos reparadores. Se desarrolló un estudio descriptivocorrelacional, de diferencias de grupo, diseño transversal no experimental, con el objetivo de analizar el impacto psicosocial de las medidas de JT, en base a una muestra intencional compuesta por 576 participantes. Los hallazgos respaldan la efectividad de las medidas combinadas de JT, la debilidad del reconocimiento y las disculpas, y diferencias en términos de afectación de la violencia.

Palabras clave: dictadura militar Argentina, violencia colectiva, medidas de justicia transicional, impacto psicosocial, afectación de la violencia. 


\section{Collective Violence and Transitional Justice ${ }^{1}$}

Transitional Justice (TJ, hereinafter) entails a wide range of responses to an abusive regime for the purpose of maintaining distance from such abuse and dealing with a past involving harsh social violence (Andrieu 2010). As a field of study, TJ has experienced an important development over the years. It includes complex debates related to democratisation, human rights and the reconstruction of the State and its institutions after periods of extreme social conflict (McEvoy 2007).

Investigating the past in order to bring clarity about what actually happened, on the one hand, and prosecuting those who were responsible for the violence on the other, are key issues to be sorted out in such periods of socio-political changes. Regarding the past, questions are raised as to what, how, where, who, why, and when the violations were committed. As for TJ itself, according to the UN (2004), it is not only aimed at the reparation of severe violations of the most fundamental human rights, but also at reconciling those groups or sectors which were involved.

The effectiveness of TJ depends, to a large extent, on the full integration of the implemented mechanisms due to their intrinsic weakness and insufficiency (Drožđek 2010). Executing a single initiative, such as the prosecution of those responsible, material compensations and institutional reforms, to name just a few, weakens TJ's effectiveness when compared to multiple and unified measures which complement each other in a cohesive and synergistic way (de Greiff 2008). Moreover, offering public apologies to victims does not meet the wide variety of needs that should be addressed, such as their rights to achieve truth and justice. Implementing remedial measures like financial compensation can be useful to satisfy immediate subsistence; but if they are not accompanied by a sustained effort to clarify what happened, they could be perceived as a bribery attempt. Conversely, seeking the truth on the abuses can be useless when reparation measures are not applied (de Greiff 2008).

Different actions must be taken to restore the trust: a) prosecutions can be regarded not only as a reinstatement of the lost legality but

1 Acknowledgment: Main Research Project "Psychosocial and cultural well-being. Memory, representations and associated beliefs". University of Buenos Aires, Secretary of Science and Technology (2014-2017). Postdoctoral fellowship (Juan Bombelli) awarded by the National Research Council of Scientific and Technical Research (CONICET): The psychosocial impact of the Truth Commission in Argentina, CONADEP. From 04/01/14 to 03/31/16. 
also as a cessation of impunity; b) historical clarification aims to reveal the crimes, identifying those responsible for them, and establishes a critical stance on what happened; c) reparations entail authentic consideration of the victim's suffering and allow the State to restore the validity of the violated rights; $d$ ) institutional reforms imply a review of the institutions' purposes and procedures; and e) last but not least, removing those who executed violence restores the victims' dignity and confidence (de Greiff 2011). When all the previous points are jointly in force, trust is not demanded but earned.

De Greiff (2011) points out that the consolidation of the legal norm in a State of democratic law is achieved only when the recognition to the victims and the reconstruction of trust are accomplished. Following Bakiner (2014), one of the main indicators of the impact of a TJ mechanism, such as the Truth Commissions (TC hereinafter), is delegitimising the perpetrators and their actions, exposing and repudiating them as the authors of violent and undemocratic acts.

If all of the above is valid, TJ can guarantee a sound framework to restore trust and, consequently, the social fabric. This is related to the so-called culture of peace (de Rivera 2014). According to the definition developed by the United Nations Educational, Scientific and Cultural Organisation (UNESCO 1995, in de Rivera 2014), a culture of peace consists of a particular set of values, attitudes and behaviours mostly shared, repelling violence and conflicts. When such values, attitudes and behaviours are embraced, clashes are prevented or solved via dialogue and negotiation.

\section{Transitional Justice in Argentina}

The systematic violations of the most fundamental human rights perpetrated by the last military dictatorship in Argentina (19761983) affected the social fabric as a whole, shattering people's basic self-beliefs, beliefs about others and the world in general. With the recovery of democracy in 1983, different transitional justice mechanisms were put in force in order to deal with the consequences of collective State violence: Truth Commission, criminal prosecutions, institutional reforms, and reparatory gestures.

However, though Bolivia was the first country in establishing TC, it was soon dissolved in view of the impossibility to specify its purpose (Schey, Shelton, and Roth-Arrianza 1997). Therefore, Argentina is considered a pioneer country in establishing the first official transitional commission of investigation. Such commission earned wide recognition 
and respect owing to its impartiality and effectiveness in achieving its primary goal: Revealing the truth, this being a matter of debate regarding other countries' commissions (Avruch 2010).

The National Commission on the Disappearance of Persons (CONADEP for its initials in Spanish) was created in Argentina by President Raúl Alfonsín, five days after taking office in December 1983. This commission had multiple purposes: to investigate the fate of missing people during the last dictatorship (1976- 1983), to investigate the violations of fundamental human rights, to find the abducted children, to report any attempt of hiding evidence or information relevant to fact clarification, and to issue a final report regarding the main conclusions of the investigation.

The report, named Never Again (Nunca más, in Spanish), collected the information described above and included some final recommendations integrating the suggestions of some human rights organisations (Crenzel 2010). The complete work resulted in more than 50,000 pages handed over to President Alfonsín, after 280 days of hard work (CONADEP 1984). A total of 8,961 missing persons were documented, a number which in the report itself remained open to posterity. The report was sent to the civil courts, not the military, for the complaints to be processed.

President Raúl Alfonsín's decision to confront the abuses of the military dictatorship was not limited to CONADEP's creation. It was only a part of a global plan to review the violent and terrifying past practices in Argentina. In his opening speech at the Legislative Palace, the President preached that he would place in the hands of Justice the important task of avoiding impunity, upholding the ethical principle stating that the end does not justify the means. He also expressed the commitment to this imperative as sustaining his acts of government. Along with CONADEP creation, Alfonsín ordered the prosecution of the commanders of the three military government boards ruling the country between 1976 and 1983, holding them ultimately responsible for the crime committed: murder, unlawful deprivation of liberty, torture, and any other crime that could be proven.

The prosecuting party adopted the strategy previously used in Ireland's court case against the United Kingdom before the European Court of Human Rights (Calcagno 2013). Given the multiplicity of human rights violations, in such a European process thirteen paradigmatic cases had been analysed as representative of an older victimised population. Consequently, the judgment of the Argentinean transition was also conducted through paradigmatic cases. The prosecutors chose those crimes that were best proven, in order to 
avoid ambiguity or misrepresentation of the criminal existence. Much of the proof was supplied by CONADEP's vast previous work.

Prosecutor Julio Strassera, based on the undertaken strategy, selected 709 cases. The Chamber dealt with 281 to issue the sentence. Important members of the military boards, general Videla and Massera, were sentenced to life imprisonment; Agosti, to four years and six months in prison; Viola, to 17 years in prison; and Lambruschini, to eight years in prison. The recommendation of the Federal Justice to continue the criminal actions at junior officers' levels created a military collective crack, tightening the bond with the government even further. This led to the controversial enactment of the subsequent Full Stop and Due Obedience laws in December 1986 and April 1987, as a result of uprising attempts against the government.

\section{Recognition of the crimes and public apologies}

The enormous influence of CONADEP and the Prosecution against the military boards brought the military institution into disrepute in the eyes of the Argentinean society. Sectors linked to the armed forces made a strenuous effort to construct a narrative using the notions of "war", "subversives", or the very unspecific term of "excesses", in order to safeguard their honour and institutional value (Salvi 2015). Even so, the military group initiated a discrediting process, catalysed by the knowledge of the past events and the protests endorsed by Human Rights organisations. Furthermore, the military uprisings and the endorsement of the above-mentioned Full Stop and Due Obedience laws led the population to mistrust the military collective and to hold them responsible for their repressive measures.

In such a social context of discredit, ten years after the process that imprisoned the military, on April 25, 1995, the head of the Army Forces, General Martín Balza, made a public statement in a television programme. This statement was the first institutional "self-criticism" of the Army, and it involved admission of responsibility for the systematic violations of human rights perpetrated during the military dictatorship. General Balza publicly instructed his subordinates to disobey any further immoral order. Without pretense, he stated that the violation of the National Constitution and the execution of immoral orders were criminal acts. According to him, intending to use unfair and immoral means to achieve fair purposes was also a crime. In such a statement, the military expressed that the Armed Forces assumed responsibility for the mistakes made in what he considered a battle between 
Argentineans and accepted institutional responsibility for the past (Balza 1995).

The message issued by Balza was the first public and official recognition of the Armed Force's responsibility for previous crimes. He sought to prevent further abuses like those committed in the past not only by urging his subordinates to disobey any immoral order and to use discernment, but also by appealing to reconciliation as a process owed to the Argentinean society, which could only be reached through dialogue and respect.

On March 24 ${ }^{\text {th }}, 2004$, Commemoration of the 1976 Argentine coup d'état, President Néstor Kirchner participated in three emblematic activities. One of them was held at the National Military College, where Army officer candidates are trained. There, he ordered the college authorities to remove the portraits of the commanders of the former dictatorship, which were hanging on the walls of the hall of honour, featuring the portraits of all former directors of the military training institute. In a brief speech to the cadets and officers, the president stated that nothing was serious enough in society to justify the participation of the Armed Forces in State terrorism. With this removal of the paintings, he indicated his intention of taking a clear position to consolidate the democratic system, banish State terrorism, and contribute to the construction of a new country. He expressed his desire that March $24^{\text {th }}$ be remembered as a living memory of what should never be done again. A few hours later, in the Higher School of Mechanics of the Navy, where the largest detention camp had operated during the dictatorship, the President signed an agreement with the Mayor of Buenos Aires City to evict the Navy from the property and turn it into a Space of Memory, for the defence and promotion of Human Rights. In his speech, the President asked for "forgiveness on behalf of the National State for the shame of having kept silent so many atrocities for twenty years of democracy".

Faced with these events, however, many people quickly made their criticisms manifest, especially those related to Unión Cívica Radical [UCR], the political party which led Alfonsín to the presidency. The criticisms that came afterwards highlighted that apologies are insufficient mechanisms and that they do not fulfil the process of rectifying and healing the past, but rather pave the way to understanding what happened, which in turn contributes to regaining confidence. 


\section{Emotional social climate}

The emotional climate is a collective affect generated by the interactions among individuals in response to economic, political, and social conditions (de Rivera 2014). Páez et al. (1997) define the social emotional climate as a collective state of mind characterised by a predominant affective tone, a certain vision of the social world and the future, and certain tendencies to act according to perceived emotions. If a climate of fear and insecurity prevails, people tend to be suspicious and cautious and they are likely to avoid social contact and to remain confined at home, postponing outings and meetings in public spaces. In a national context plagued with collective violence, the perceived emotional climates may also vary depending on the geographic sectors analysed. As Páez and Liu (2011) show in their study, the physical and socio-political closeness to a place marked by violence explains the intensity of a particular emotional climate, so the closer people are to the zone of conflict, the more negatively they perceive the climate.

Following Martín-Baró (2003), after socio-political terror, the affected people are left with a narrower social life, an undermining of their interpersonal relationships and deterioration in their social coexistence. When thousands of people are threatened by a political regime, the feeling of vulnerability and fear affects the behaviour of the affected human group (Lira and Castillo 1991).

In post-conflict situations, it is interesting to note the role that collective emotions play in the construction of peace or in maintaining situations of tension and violence. People respond emotionally not only to events based on their own experiences, but also to those based on social frameworks of reference. These frameworks provide guidelines for what is expected and appropriate to feel and do.

An empirical study was conducted to analyse the psychosocial impact of the work of CONADEP and other transitional justice measures in Argentina.

The specific goals were as follows:

- to inquire into people's knowledge, approval, and effectiveness of TJ measures;

- to explore the elicitation of emotions associated with the violent past and perception of the social emotional climate:

- to determine whether there were differences in the aforementioned psychosocial variables based on the degree of exposure to violence: direct victim, indirect victim, or unaffected. 


\section{Method}

A descriptive-correlational study of group difference was developed, with a non-experimental cross-sectional design.

\section{Participants}

The non-probabilistic, intentional sample was composed of 576 participants (39.8\% men; $60.2 \%$ women; Mean Age $=36.68$ years old; $S D=13.98$, range $18-83$ years). Besides, $83.7 \%$ of the participants lived in Buenos Aires province and $16.3 \%$ in the Autonomous City of Buenos Aires.

Nine percent $(9,2 \%)$ of the total sample identified themselves as direct victims (DV) of the dictatorship violence, having been kidnapped, imprisoned without prior trial, tortured, threatened, exiled, removed from office, or other forms of violence; $24.1 \%$ considered themselves to be indirect victims (IV) and $66.7 \%$ to be unaffected (UA).

\section{Variables and instruments}

A self-administered questionnaire was applied integrated by:

\subsection{Level of exposure to violence}

Two items were included to establish the level of affectation by violence and define the categories of direct affectation, indirect affectation and no affectation: "Do you consider yourself a victim of violence by the State or its agents (police, Armed Forces, security agencies, etc.) between 1970 and 1983?" Participants were asked to indicate what type of violence they had gone through, the options being dismissal from office/employment, prison, clandestine detention camp, torture or ill-treatment, exile or relegation, or others. For indirect victimisation, the following question was asked: "Were there victims of violence by the State or its agents (police, Armed Forces or security agencies) among your relatives or close friends between 1970 and 1983?" If so, the type of relationship was requested (father/mother, grandparents, siblings, children, nephew, uncles/aunts, cousins, friend, partner, other), as well as the type of violence suffered (same as previous options in addition to "missing/executed"). 


\subsection{Impact of transitional justice measures}

Degree of self-perceived information on the period of violence, CONADEP, Prosecution of the Military Boards, Prosecutions for crimes against humanity.

Four questions were asked to evaluate how much the participants knew about the dictatorial period and the three TJ measures mentioned: "How much knowledge do you have about what happened in the period of violence?" ( 1 = Nothing to $4=$ Much). Later, participants were asked about their knowledge of TJ measures through Yes-No questions. In the affirmative cases, the respondents were asked to indicate the degree of knowledge using options ranging from $1=$ Very little to $5=$ Very much.

The response values were recalculated involving six possibilities, where $1=$ No information, to $6=$ Lot of information. Subsequently, a new variable encompassing the answers was created. The reliability for the degree of total knowledge of TJ measure was satisfactory (3 items; $\alpha=.89$ ).

\subsection{Knowledge of institutional apologies}

Participants answered two questions: "Do you know about the statements and apologies made by General Balza and President Kirchner?" (Yes/No), "Do you know about the statements and apologies made by President Kirchner?" (Yes/No).

Approval of TJ measures were evaluated adapted from Gibson (2004), assigning an item to each one of them: "With regard to the performance of the following institutions or events, do you approve of: the actions taken by CONADEP, Prosecution of the Military Boards, Prosecution for crimes against humanity, Full Stop and Due Obedience laws, Pardons, Pardons annulment, Declaration of unconstitutionality of pardons..." ( 1 = Totally disapprove to $4=$ Totally approve).

The scores were grouped into two sets, depending on whether they were the measures aimed at Truth and Justice (CONADEP; Prosecution of the Military Boards; Recent Prosecutions for crimes against humanity; Pardons annulment; Unconstitutionality of Full Stop and Due Obedience laws) or the measures that promoted impunity (Full Stop and Due Obedience laws; President Menem Pardons to the Military). 


\subsection{General evaluation and effectiveness of TJ measures}

A question was asked to evaluate the general performance: "It is often said that the following institutions and events (CONADEP, Prosecution of the Military Boards; Prosecutions of crimes against humanity) fulfilled important objectives. In your opinion, would you say that their performance was...?" ( 1 = Very bad to 4 = Very good).

In addition, four questions evaluating the perception of effectiveness asked the participants to what extent they considered the measures attained the following objectives: helped the families of the victims to find out what happened to their loved ones; contributed to creating an inclusive story that incorporated the different national groups into a common narrative; helped to prosecute those guilty of atrocities of human rights violations; prevented human rights violations from happening again at present or in the future $(1=$ To not extent to $4=$ To a great extent).

The average of the 12 items was calculated in a new variable, subsequently grouped to calculate the global efficacy assigned to these three measures, yielding high reliability (12 items; $\alpha=.92$ ).

\subsection{Evaluation of apologies}

Four questions adapted from Etxebarría et al. (2010) inquired about: a) the sincerity of the apologies made by General Balza and President Kirchner; b) their effectiveness in promoting empathy and intergroup trust ( $1=$ Totally disagree to $4=$ Totally agree).

The two items were grouped in a new variable by averaging the scores recorded as an indicator of the overall effectiveness of apologies. Reliability was acceptable ( 2 items; $\alpha=.74$ ).

Emotional impact associated with the TJ measures and the period of violence (Echebarría and Páez 1989): participants were asked to respond ( $1=$ To not extent to $7=$ To a great extent) to what extent the period of violence and each of the transitional justice mechanisms generated certain emotions (sadness, anger, guilt, shame, fear, joy, pride and hope).

The items were grouped into two large dimensions called negative emotions (sadness, anger, guilt, shame and fear) and positive emotions (joy, pride and hope). Reliability indices were satisfactory. Negative emotion subscale: $\alpha=.87$ (CONADEP: $\alpha=.75$; Prosecution of the Military Boards: $\alpha=.71$; Prosecution for crimes against humanity: $\alpha=.72$ ). Positive emotion subscale $(\alpha=.90)$ (CONADEP: $\alpha=.81$; 
Prosecution of the Military Boards: $\alpha=.84$; Prosecutions for crimes against humanity: $\alpha=.85)$. Scales referring to emotional activation with respect to the period of violence yielded poor indices: negative emotions ( 5 items; $\alpha=.60$ ) and positive emotions ( 3 items; $\alpha=.49$ ).

Social and emotional climate (Páez et al. 1997; de Rivera 1992): four questions evaluated the perception of the positive social climate (solidarity and mutual aid and trust in institutions) and negative climate (anger and hostility, sadness and passivity) $(1=$ Totally disagree to $5=$ Totally agree).

The four items were grouped into two dimensions: positive climate (solidarity and trust) and negative climate (anger and sadness). Reliability was acceptable for the positive climate scale $(\alpha=0.65)$ and satisfactory for the negative climate $(\alpha=0.76)$.

Items selected from the Emotional Climate Scale (de Rivera 1992): Eight items, regrouped into four dimensions, described socio-structural situations and social relationships inducing negative and positive emotions in general: 1) Security (e. g. "Do you think that people feel unsafe because the level of violence that exists does not allow people to live in peace") (two items; $\alpha=0.50$ ); 2) Trust (e.g. "Do the different political, ethnic and religious groups of this country trust each other?") (two items; $\alpha=0.64$ ); 3) Fear ("People are afraid of meeting publicly to speak, organise or protest peacefully") (two items; $\alpha=0.77$ ); 7) Hopelessness ("Hopelessness in this country is such that many people want to leave") (two items; $\alpha=0.68)(1=$ Totally disagree to $7=$ Totally agree).

\section{Data analysis}

Descriptive statistics analyses were carried out. Cronbach's alpha indices were calculated to assess the reliability of the dimensions used. To analyse the relations between the different variables, one-way ANOVAs were used. The correlation coefficient - Pearson's $r$ - was calculated.

\section{Results}

\subsection{Knowledge and general assessment}

Participants declared a relatively high degree of knowledge about what had happened in the past, $62 \%$ of the sample reported having a moderate to a substantial amount of knowledge. 
As for the knowledge on the TJ measures, the results are diverse: $45.8 \%$ said they had moderate or enough information about CONADEP and $1.7 \%$ reported having a vast knowledge. Regarding the Prosecution of the Military Boards, 33.4\% reported having moderate information, followed by those who indicated having enough $(22.4 \%)$, and those who declared having a great deal of information (1.7\%).

Regarding the statements and public apologies of General Balza and former President Néstor Kirchner, the trend towards ignorance was substantial. In the case of Balza's recognition, more than half of the participants stated that they were not aware of it (65.6\%), while the other half $(51.4 \%)$ reported not knowing about President Kirchner's pronouncement.

The more recent prosecutions for crimes against humanity carried out in recent years, registered a higher level of knowledge. Participants said they knew enough (38.4\%) and a great deal (25.7\%), representing $64.1 \%$ of the total.

Table 1

\section{General evaluation of TJ measures and the sincerity of Balzas's and Kirchner's pronouncements}

\begin{tabular}{|c|c|c|}
\hline & Mean & SD \\
\hline \multicolumn{3}{|l|}{ In your opinion, would you say that } \\
\hline CONADEP's action was ...* & 3.18 & .65 \\
\hline $\begin{array}{l}\text { the performance of the Prosecution of the Military Boards } \\
\text { was ...* }\end{array}$ & 3.13 & .71 \\
\hline $\begin{array}{l}\text { that the prosecutions that have been held in recent years } \\
\text { to prosecute those responsible for the atrocities committed } \\
\text { during the last dictatorship were ...* }\end{array}$ & 3.11 & .78 \\
\hline
\end{tabular}

General evaluation of the actions

Attribution of sincerity to...*

Balza's recognition**

Kirchner's apologies **

* $1=$ Very bad $/ 4=$ Very good.

** $1=$ Totally agree to $4=$ Totally disagree. 
When evaluating CONADEP's performance (see Table 2), the general opinion was that its work was remarkable, exceeding the theoretical average. The Prosecution of the Military Boards was also judged as a 'good' historical event regarding its original goal. Most participants (55.6\%) considered that the prosecutors' performance was good, in addition to $29.8 \%$ who thought it was very good.

As for the recognition of criminal acts and apologies pronounced by General Balza and President Kirchner, participants negatively evaluated a central aspect-their sincerity - in these gestures. The few participants who reported knowing what was stated by the military chief believed that his statement was rather insincere. Those who reported knowing about President Kirchner's apologies evaluated them as relatively sincere, although there was some dispersion in the answers.

When considering the prosecutions for crimes against humanity carried out in recent years, in general terms, the participants evaluated them in a positive way, in keeping with the evaluation related to the prosecution of the former commanders of the dictatorship conducted at the beginning of the democratic period. The implementation of these trials was viewed as quite good whereas only $15.5 \%$ of the participants valued their performance as negative.

\subsection{Specific effectiveness of the TJ mechanisms implemented}

CONADEP and its final product, the Never Again Report, was by far the measure that received the greatest effectiveness response (see Table 2). Participants considered that it was considerably effective in helping the victims' families to find out what happened to their loved ones and even more effective in helping to prosecute those responsible for human rights violations. To a lesser extent, but with a positive consensus, it was also evaluated as effective in ensuring that such violations would not occur again, either in the present or in the future, and in creating a common narrative for the different groups involved in political violence.

The Prosecution of the Military Boards was also considered effective. Participants stated that it fundamentally contributed to prosecuting those responsible for the massive violations of the rights of so many citizens. It also made it possible to shed light on what happened and contributed to preventing a further return to such generalised violation of rights. Similar to CONADEP's evaluation, the item in which the prosecution was considered a little less effective was that related to its contribution to creating an integrative narrative. 


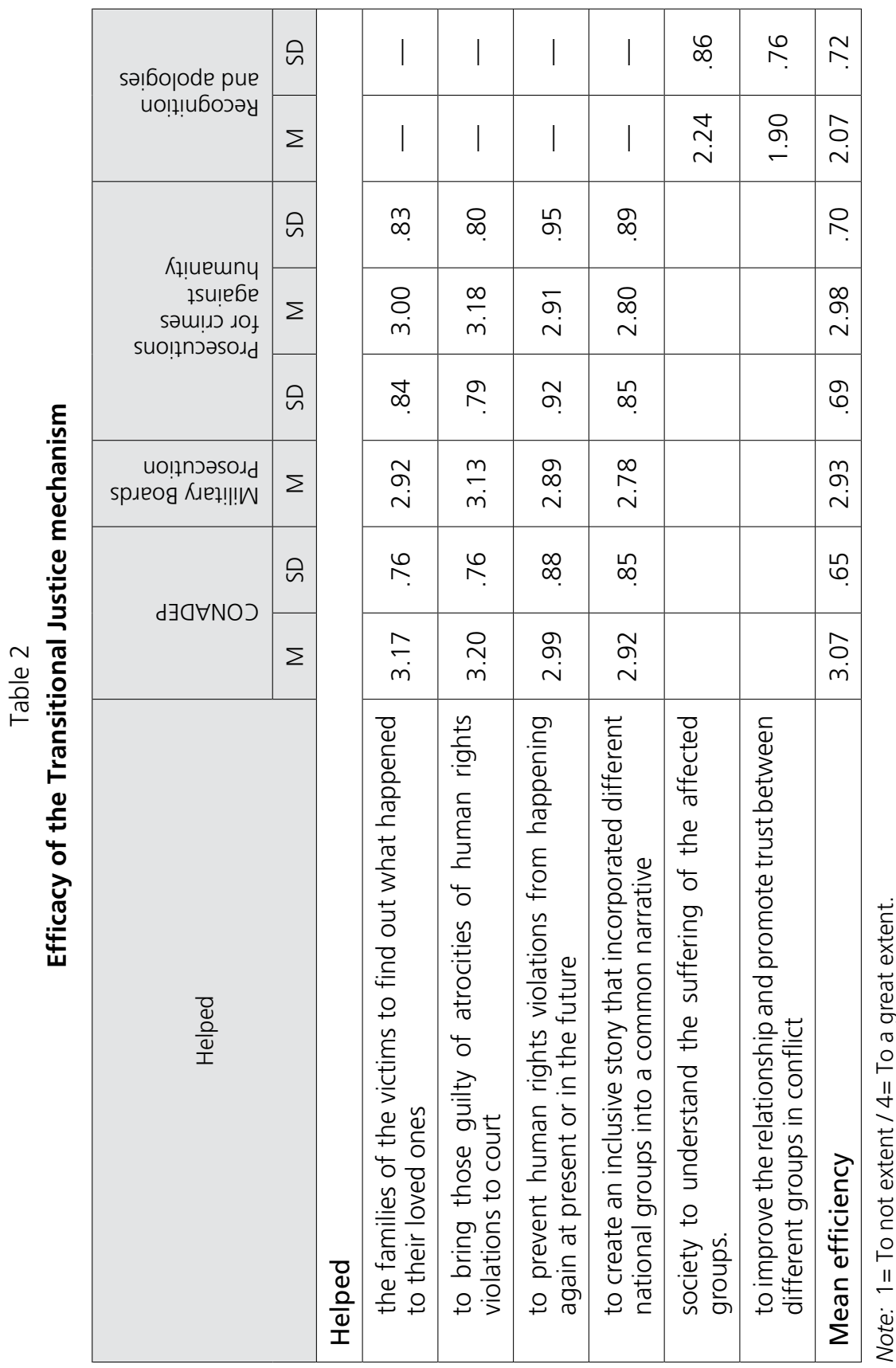


In line with the poor opinion of the sincerity of the General and the President, the perception about the effectiveness of their recognition of criminal acts and apologies was considered quite low, both in terms of their contribution to understanding the suffering of the victims, that is, an empathic attitude towards those who most suffered, and in terms of their contribution to improving the relations among the involved groups and promoting trust between them. These were the measures that the respondents disapproved of the most, as far as efficacy was concerned.

The prosecutions for crimes against humanity carried out in recent years were valued as quite effective both in helping to prosecute and convict the perpetrators as well as clarifying what happened, providing knowledge to the victims' families. To a lesser extent, the respondents believed that these prosecutions were effective in ensuring that severe human rights violations would not be repeated, and assigned a low rate of effectiveness to the creation of an inclusive narrative.

CONADEP was the measure considered the most effective, followed by the recent prosecutions of crimes against humanity, while the institutional apologies by the Military Boards were perceived as the least effective measures.

\subsection{Approval of transitional measures}

As shown in Table 3, there was high approval of all those transitional measures that promoted the knowledge and prosecution of those responsible for crimes against humanity, along with intense disapproval of those measures that guaranteed impunity and blocked the rights to truth and justice. The mechanisms resulting in the greatest approval were the prosecutions, with a prominent position for the trial against the military dictatorship board, followed by the local Truth Commission, and a negligible lower approval of the measures that led to the resumption of the prosecutions.

CONADEP's work was highly valued, reaching approval of $93.1 \%$. The prosecution against the military board obtained approval of $92.5 \%$ and recent prosecutions for crimes against humanity $89.3 \%$. Pardons law annulment was approved by $82.6 \%$, and the declaration of unconstitutionality of the Impunity Laws was welcomed by $81 \%$ of the participants.

The Full Stop and Due Obedience laws put in force during Alfonsín's government, triggered by military uprisings, received high disapproval (60.8\%), although more than a third of the participants 
viewed them favourably. The pardon granted by president Menem, who took office after Alfonsín, to the leaders of the former dictatorship and to some civilians charged with serious crimes committed during the period, also received extensive disapproval (86.8\%).

Table 3

Degree of approval of TJ measures

\begin{tabular}{|l|r|r|}
\hline & Mean & SD \\
\hline CONADEP & 3.49 & .69 \\
\hline Prosecution against Military Boards & 3.61 & .72 \\
\hline Laws of Due Obedience and Full Stop & 2.09 & 1.13 \\
\hline Pardons to the military (President Menem) & 1.49 & .85 \\
\hline $\begin{array}{l}\text { Recent prosecutions against military personnel for crimes } \\
\text { against humanity }\end{array}$ & 3.51 & .83 \\
\hline Pardons Annulment & 3.32 & 1.00 \\
\hline Unconstitutionality of Due Obedience and Full Stop laws & 3.24 & 1.03 \\
\hline Approval of measures for justice and truth & 3.44 & .68 \\
\hline Approval of measures for impunity & 1.81 & .90 \\
\hline
\end{tabular}

Note: 1 = Totally disapprove to $4=$ Totally approve.

9.4. Emotional impact associated with the period of violence, CONADEP and Prosecutions

As can be seen in Table 4, although both positive and negative emotions did not exhibit great intensity, participants stated that when thinking about the period of dictatorial violence they feel more negative than positive emotions. The prevailing emotion was sadness, followed by anger and shame. Some activation of hope was also detected.

A similar trend of emotional evocation was associated with CONADEP, where sadness prevailed, followed to a lesser extent by anger. Also, CONADEP's work raised more hope than anger. 
Thinking about the Prosecution against the Military Dictatorship Board, in general, aroused positive emotions to a greater extent than negative ones. In this case, the hope associated with the trial of the de facto government leaders became more significant than emotions such as anger, with pride prevailing over sadness. Also, when thinking about the more recent prosecutions of crimes against humanity, positive emotions prevailed over negative ones. Hope stood out, followed by joy and pride.

Table 4

Emotions associated with TJ events and mechanisms

\begin{tabular}{|c|c|c|c|c|c|c|c|c|}
\hline \multirow{2}{*}{ Emotions } & \multicolumn{2}{|c|}{ Violent Period } & \multicolumn{2}{|c|}{ CONADEP } & \multicolumn{2}{|c|}{$\begin{array}{c}\text { Prosecution } \\
\text { against the } \\
\text { Military Boards }\end{array}$} & \multicolumn{2}{|c|}{$\begin{array}{c}\text { Prosecutions } \\
\text { for crimes } \\
\text { against } \\
\text { humanity }\end{array}$} \\
\cline { 2 - 10 } & Mean & SD & Mean & SD & Mean & SD & Mean & SD \\
\hline Negative & 3.46 & 1.13 & 2.69 & 1.35 & 2.39 & 1.25 & 2.12 & 1.15 \\
\hline Sadness & 5.41 & 1.63 & 3.99 & 2.26 & 2.79 & 2.12 & 2.43 & 1.98 \\
\hline Anger & 4.42 & 2.05 & 3.44 & 2.24 & 3.44 & 2.21 & 2.99 & 2.05 \\
\hline Fear & 2.64 & 1.82 & 2.09 & 1.67 & 1.91 & 1.58 & 1.68 & 1.34 \\
\hline Shame & 3.52 & 2.35 & 2.69 & 2.14 & 2.68 & 2.13 & 2.39 & 1.96 \\
\hline Guilty & 1.45 & 1.10 & 1.41 & 1.06 & 1.27 & .89 & 1.27 & .88 \\
\hline Positive & 1.89 & 1.07 & 2.70 & 1.80 & 3.28 & 1.99 & 3.54 & 2.03 \\
\hline Joy & 1.21 & .85 & 2.17 & 1.95 & 3.10 & 2.26 & 3.41 & 2.36 \\
\hline Pride & 1.36 & 1.17 & 2.57 & 2.22 & 3.17 & 2.38 & 3.30 & 2.40 \\
\hline Hope & 3.10 & 2.20 & 3.54 & 2.25 & 3.76 & 2.24 & 4.04 & 1.97 \\
\hline
\end{tabular}

Note: $1=$ To no extent to $7=$ To a greater extent.

9.5. Perception of the social emotional climate

The prevalence of a negative social climate perception was observed, characterised by hostility and anger among people, 
sadness and bad mood. The positive climate indicators seemed to be neutralised since, although the existence of solidarity and mutual aid was perceived -indicators of good social capital - there was low trust in the institutions (see Table 5).

Table 5

\section{Social emotional climate}

\begin{tabular}{lcr}
\hline \multicolumn{1}{c}{ The climate of this country is one of... } & Mean & SD \\
\hline Negative & 3.28 & 1.01 \\
Anger, hostility, aggressiveness among people & 3.49 & 1.08 \\
Sadness, passivity, bad mood & 3.09 & 1.17 \\
Positive & 2.59 & .88 \\
Solidarity, mutual aid & 2.95 & 1.06 \\
Trust in the institutions & 2.24 & 1.00 \\
\hline
\end{tabular}

Note: $1=$ Totally disagree to $5=$ Totally agree.

Participants perceived that those around them felt somewhat insecure (Mean $=2.90, S D=1,46)$ and fearful (Mean $=2,74 S D=1,60)$, noted little trust in the different national groups (Mean $=2,50$, $S D=1,17)$, which affected joint work and cooperation to achieve national well-being. Consistent with this perception of low confidence, hopelessness punctuation is high (Mean $=4.09, S D=1.55$ ).

\subsection{Associations between the knowledge of TJ measures, evaluation of their effectiveness, and social emotional climate}

Introducing exposure to violence as a co-variable, Table 6 shows that greater knowledge and attribution of efficacy to measures associated with a more positive perception of the emotional climate, along with the perception of greater security and -though unless non-significant-, greater trust between groups in society. The lack of knowledge and effectiveness attribution was related to a negative perception of the social emotional climate, more anger, hostility and sadness, and more fear and hopelessness. The same tendency towards a perception of a positive social emotional climate emerged in connection with the familiarity with the official pronouncements and apologies. 
Table 6

Relationships between TJ measures knowledge, effectiveness and social emotional climate controlled by exposure to violence

\begin{tabular}{lccc}
\hline & $\begin{array}{c}\text { CONADEP \& } \\
\text { Prosecutions } \\
\text { Knowledge }\end{array}$ & $\begin{array}{c}\text { CONADEP \& } \\
\text { Prosecutions } \\
\text { Effectiveness }\end{array}$ & $\begin{array}{c}\text { Apologies } \\
\text { Effectiveness }\end{array}$ \\
\hline Knowledge of CONADEP \& prosecutions & - & $.238^{* *}$ & $.220^{* *}$ \\
Effectiveness of CONADEP \& prosecutions & $.238^{* *}$ & - & $.307 * *$ \\
Effectiveness of apologies & $.220 * *$ & $.307 * *$ & - \\
Positive Climate & $.185^{* *}$ & $.317^{* *}$ & $.342^{* *}$ \\
Negative Climate & $-.155^{* *}$ & $-.160^{* *}$ & $-.279 * *$ \\
Security & $.305^{* *}$ & $.215^{* *}$ & $.376^{* *}$ \\
Trust & .047 & $.240 * *$ & $.286^{* *}$ \\
Fear & $-.183^{* *}$ & $-.142 * *$ & $-.304 * *$ \\
Hopelessness & $-.312 * *$ & $-.361 * *$ & $-.464 * *$ \\
\hline
\end{tabular}

Note: ${ }^{* \star} p<.01$. Co-variable: Exposure to violence (df, 410).

Table 7

Knowledge and evaluation of TJ mechanisms, social emotional climate by degree of knowledge of official recognition and apologies controlled by exposure to violence

\begin{tabular}{lcccc}
\hline & \multicolumn{2}{c}{ Apologies } & & \\
\cline { 2 - 3 } & $\begin{array}{c}\text { No } \\
\text { knowledge }\end{array}$ & Knowledge & F(gl) & $P$ \\
\hline Knowledge of CONADEP \& prosecutions & 3.28 & 4.32 & $125.340(1,566)$ & .000 \\
Effectiveness of CONADEP \& prosecutions & 2.87 & 3.10 & $14.192(1,518)$ & .000 \\
Effectiveness of apologies & 1.81 & 2.27 & $51.268(1,543)$ & .000 \\
Positive Climate & 2.35 & 2.77 & $22.587(1,562)$ & .000 \\
Negative Climate & 3.51 & 3.09 & $19.633(1,560)$ & .000 \\
Security & 2.51 & 3.23 & $25.556(1,483)$ & .000 \\
Trust & 2.34 & 2.62 & $6.700(1,564)$ & .010 \\
Fear & 3.12 & 2.42 & $24.476(1,564)$ & .000 \\
Hopelessness & 4.66 & 3.63 & $54.067(1,555)$ & .000 \\
\hline
\end{tabular}

Note: Co-variable: Exposure to violence. 
As shown in Table 7, in controlling by exposure to violence, it is clear that the knowledge of the apologies was associated with the knowledge of other transitional measures, and the attribution of greater effectiveness and higher sincerity to the pronouncements. Along this line, knowledge of the apologies was associated both with the perception of a more positive social emotional climate, characterised by solidarity, trust and security, and with a perception of a lower prevalence of emotions such as anger, fear and hopelessness.

The better evaluation of the effectiveness of mechanisms, intended as reparations, the more positive the evaluation of the social context was, leading to the perception of a lower prevalence of negative climate.

\subsection{Differential profiles according to exposure to violence}

The degree of exposure to violence yielded differential response profiles (see Table 8) concerning the degree of knowledge about the violent period and the TJ measures related to truth clarification and retributive justice. Unequal opinions were also registered in the approval of the achievements of the different measures implemented over time and the global evaluation of the effectiveness of the pronouncements and apologies.

Direct victims, in general, knew more about the period of violence than did the unaffected respondents. Direct victims were the ones who had the greatest knowledge about TJ measures and differed from both indirect victims and unaffected participants. There were also differences between the last two subgroups, where the indirect victims reported higher levels of knowledge than the unaffected ones. In addition, direct victims were distinguished from unaffected respondents in terms of the perceived efficacy of what CONADEP, the prosecutions to the dictatorship's military board and the recent prosecutions for humanity crimes have accomplished. The former group attributed more success to the measures, although such tendency was different for recognition and apologies. Indirect victims and unaffected participants differed in their appreciation of effectiveness, with the former reporting higher levels. Thus, even when the participants held a generally critical stance regarding the efficacy of both pronouncements to promote empathy and understanding of the suffering of those most affected, as well as to foster trust between the groups in conflict, the indirect victim group was the least critical. 


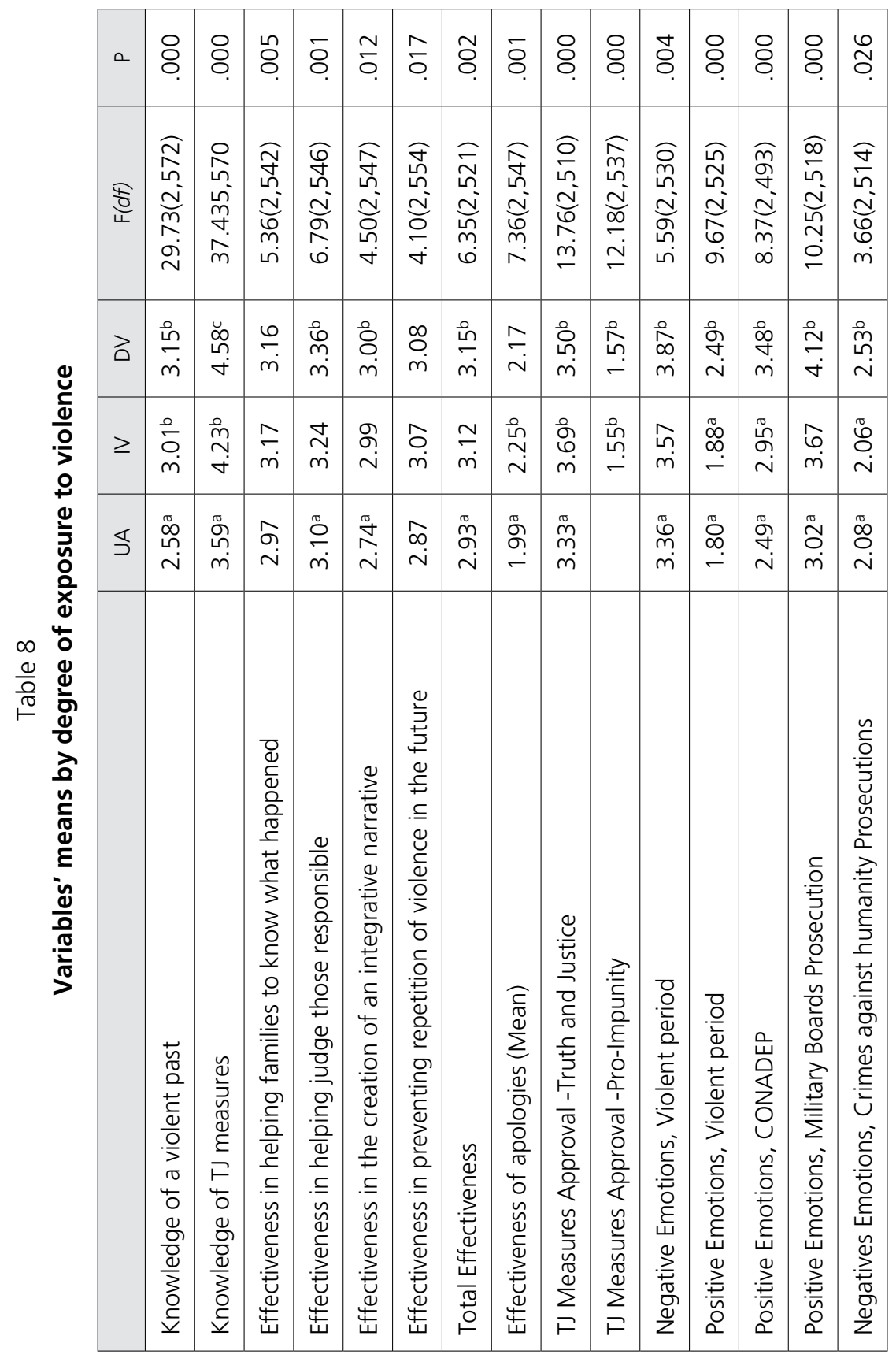




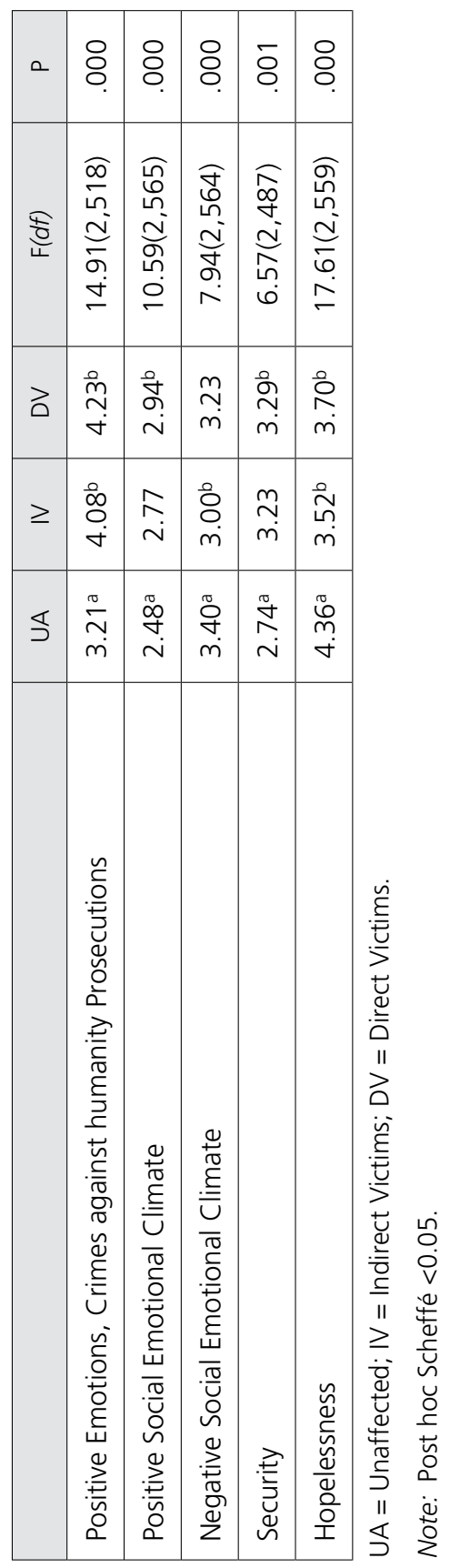


Regarding the approval of the TI measures, differences between the indirect victims and the unaffected respondents were verified, with the former group exhibiting higher approval. As for the level of approval of other measures blocking the clarification and prosecution of those responsible for the crimes during the dictatorship, such as the Full Stop and Due Obedience laws and the pardons granted by president Menem, differences were found between the unaffected group and the victims (direct and indirect), where the last two subgroups equally disapproved of the aforementioned measures.

Regarding the dictatorship period, those directly affected by violence showed greater activation of negative and positive emotions, in comparison with the unaffected group. In relation to CONADEP's work and the prosecution of the Military Boards, direct victims experienced a greater intensity in emotions such as pride, hope and joy. No differences were observed in the negative emotions. As for the emotions generated by the recent prosecutions for crimes against humanity, a double contrast was detected: direct victims reported a greater intensity of negative emotions compared with the indirect victims while the direct and indirect victims differed from the unaffected respondents, showing a greater activation of positive emotions.

The perception of the social emotional climate was also sensitive to the degree of victimisation, given that the unaffected perceived a positive climate to a lesser extent than the direct victims and a more negative climate than the indirect victims. Those affected by State terrorism could be expected to show a more pessimistic and hopeless position; however, they reported the opposite. It became clear that the perception of the context was influenced by the restorative effects of the implemented mechanisms. The pattern was similar for insecurity and hopelessness, the unaffected perceived a more negative climate compared to the victims in general.

\section{Conclusions}

Moderate knowledge about the restorative measures taken in Argentina after the dictatorship is in line with findings of previous studies conducted in different countries (Arnoso et al. 2017; Gabisirege and Babalola 2001; Reyes et al. 2015; Stein et al. 2008). Also, the little information that the population reported having on CONADEP, its work and its final report, corroborates the findings by Arnoso et al. (2013). 
Beyond the medium-low levels of knowledge about the TJ measures, in general, it is important to highlight the good evaluation that CONADEP and the prosecutions deserve, indicating that the scarce knowledge does not prevent the citizens from valuing or placing expectations on this type of mechanism, as observed by Lundy and McGovern (2008) for the case of Ireland. In addition, CONADEP's performance follows what Hayner (1994) mentions with respect to the positive power that Truth Commissions have when they receive State support and the endorsement of Human Rights Organisations. In addition, when TCs managed to interview a large number of victims and prepared a final report, which was disseminated and accepted by society, and used against those responsible, prompting concrete reparatory actions. The assessment of the local TC allowing victims' relatives to know what happened is a relevant finding. Its effectiveness perception attests to the work of resistance against impunity, silencing and denial presented by TCs in transitional periods (Robben, 2005).

The general lack of knowledge about General Balza and President Kirchner pronouncements added to the generalised disbelief about the sincerity of both and enables some considerations. The little sincerity attributed to what the chief of the armed forces expressed may be due to the general distrust linked to his belonging to the military group. Also, this perception of insincerity can be explained by the non-representativeness of the group for which he tried to speak (Canelo 2010). As Salvi (2012) points out, Balza's self-critical speech did not contribute with valuable information on the fate of the missing persons, and the message was diluted by the Final Point and Due Obedience laws, which blocked the progress of criminal investigations and assignment of responsibilities. This is possibly a warning about the inherent weakness of each TJ measure to deal with the consequences of collective violence, and therefore, the need for articulation with other measures to enhance its effects on the reconstruction of society (Drožđek 2010; Páez 2010).

As for President Kirchner, following James (2008), his message as an attempt at an official apology also has some weaknesses. The emotionality that should accompany the message of forgiveness was evidently lacking, and this affected the evaluation of the message transmitted (Andrieu 2009), in particular, when he expressed "the shame of having been silent for more than 20 years of democracy", omitting the actions promoted by President Alfonsín, CONADEP's creation and the Prosecution of the Military Boards.

The findings not only corroborate the results of a previous local investigation (Zubieta, Bombelli and Muratori 2015), but are also similar 
to the evaluation of the apologies offered in Chile and Paraguay, where a medium-low level of sincerity was perceived, along with a trend to consider that they have been more effective in understanding the suffering of the affected people than in promoting trust in the social groups involved (Arnoso and Da Costa 2015; Bobowik et al. 2017).

In terms of emotions, the prevalence of a negative emotional impact with respect to the dictatorial period, where sadness, anger and even shame predominate, allows us to infer that the representation of the past is associated with serious and cruel events, characterised by human intentionality. However, in the activated pattern of emotions, it is worth highlighting the presence of hope as a promising expectation of confidence and desire of a prosperous future.

Emotions as a collective process show a pessimistic overview of the social situation, characterised by the predominant perception of a negative social emotional climate, corroborating what has been detected over the last few years in previous studies (Muratori and Zubieta 2013; Zubieta, Delfino, and Fernández 2008). Emotions such as anger and hostility dominate the social scene, making people feel insecure. This does not mean that people do not show solidarity with each other, offering help, but sadness and passivity gain ground due to the perception of little trust between social groups, preventing cooperation in the pursuit of common well-being. This is probably associated with the so-called "crack" that is actually widely debated in Argentina, deeply affecting institutional functioning.

Correlations show that both, the knowledge and the consideration of the effectiveness of TJ mechanisms, are linked to three critical axes for community life and peaceful coexistence. The positive association with a more positive and less negative emotional climate accounts for its contribution to social well-being. Páez, Basabe and González (1997) explain that different emotional climates are characterized by specific representations of the social world, the future, and tendencies to action triggered by the perceived emotions. Greater knowledge of what has been done, as well as the evaluation of the effectiveness in this regard, is consistent with higher perception of emotions that facilitate rapprochement with others, reinforcing ties and social capital. In a complementary way, knowledge and a sense of effectiveness are associated with a lower perception of emotions such as anger, sadness, hopelessness and fear, which motivate self-protective behaviors of withdrawal and inhibition of social contact.

The contribution of knowledge and the effectiveness of TJ mechanisms can be highlighted as a trend to reverse fear and insecurity climates typical of dictatorial regimes, stimulating the development of 
prosocial behaviors and participation in community life. The evident contribution of these measures is also remarkable in a culture of peace construction (de Rivera 2014). This constructive process, although imperfect and perfectible, draws on what has already been done and presents new challenges linked to ever-changing factors.

Finally, past violence affectation coherently yielded differences. Direct victims showed greater knowledge of both, the violent past and the transitional justice mechanisms gradually implemented upon the return of democracy, as well as a greater emotional affectation.

The best evaluation of CONADEP and prosecutions effectiveness and approval by direct victims are related to their need to know the truth and end impunity. Through transitional measures, they are symbolically restored as citizens. De Greiff $(2012 ;$ 2014) proposes that the implementation of different transitional tools helps to reverse the implosion of basic beliefs, the feeling of vulnerability, powerlessness and defenselessness generated by the abuse suffered. Recognition would result in the assignment of greater approval and effectiveness.

Beyond the weighting of mechanisms such as TC and prosecutions, some studies reveal that the people who are mostly highly affected by violent actions are less likely to accept institutional apologies and therefore evaluate them in a negative light (Blatz et al. 2009; Etxebarría et al. 2010; Manzi and Gonzalez 2007). Differences observed between victims and the unaffected group with respect to impunity laws and pardons show that the former group have the most radical position, according to the pain that inhabits them.

As for greater activation of negative than positive emotions when thinking about the dictatorial period, those who were victimized reported higher levels of negative as well as positive emotionality. It is important to highlight the substantive and persistent differentiation between the victims and the unaffected group in the positive emotional impact associated with CONADEP, the prosecution of the Military Board and the subsequent prosecutions of crimes against humanity. The transitional measures implemented in the local context have managed to bring personal benefit to the victims on the emotional level. Institutional mediation in dealing with the repressive past, with its respective milestones, has allowed them to transform their painful experiences in such a way that what is becoming more and more salient is no longer sadness, anger, shame or fear, but joy, pride and hope.

The results of this study contradict the expectation that victims have a less positive perception of the social emotional climate, precisely relative to the reduction of their status and the breakdown 
of benevolent basic beliefs about the social world and the future that usually comes coupled with experiences of collective violence (JanoffBulman 1992). Even with the salience of a negative emotional climate, the victims in general make a less critical evaluation, perceiving greater solidarity, security and trust in the institutions.

Using an intentional sample, this line of research will further replicate the study by both, analyzing the mediate role of TJ measures in social emotional climate and exploring differences by grouping people in terms of gender, age and religiosity.

\section{References}

Andrieu, Kora. 2009. «'Sorry for the Genocide'. How public apologies can help promote national reconciliation.» Millenium: Journal of International Studies 38, no. 1: 3-23.

Andrieu, Kora. 2010. "Transitional justice: A new discipline in Human Rights.» Online Encyclopedia of Mass Violence. Accessed February 4, 2013 http:// www. massviolence.org/PdfVersion?id_article=539.

Arnoso, Maitane, Juan I. Bombelli, Marcela Muratori, Silvia Mele, \& Elena Zubieta. 2013. "La CONADEP y el Informe "Nunca Más": Conocimiento, eficacia y emociones asociadas.» Anuario de Investigaciones XX: 197-205.

Arnoso, Maitane, \& Silvia Da Costa. 2015. "Actitudes hacia el pasado de violencia colectiva y actividades de Justicia Transicional en Uruguay.» Psicologia Política, 15, no. 32: 185-201.

Arnoso, Maitane, Marcela Muratori, Juan I. Bombelli, \& Elena Zubieta. 2017. «Evaluación de medidas retributivas y restaurativas luego de pasados políticos traumáticos: una mirada al caso argentino.» Cuadernos FHyCS UNJu 52: 211-233.

Avruch, Kevin. 2010. "Truth and reconciliation commissions: problems in transitional justice and the reconstruction of identity.» Transcultural Psychiatry 47, no. 1: 33-49. Doi: 10.1177/1363461510362043

Bakiner, Onur. 2014. "Truth Commission Impact: An Assessment of How Commissions Influence Politics and Society.» International Journal of Transitional Justice 8, no 1: 6-30.

Balza, Martín. 1995. Mensaje al país. Accessed in http://www.desaparecidos. org/nuncamas/web/document/militar/balza95.htm

Blatz, Craig W., Karina Schumann, \& Michael Ross. 2009. "Government apologies for historical injustices.» Political Psychology 30, no. 2: 219-241.

Bobowik, Magdalena, Darío Páez, Maitane Arnoso, Manuel Cárdenas, Bernard Rimé, Elena Zubieta, \& Marcela Muratori. 2017. «Institutional apologies and socioemotional climate in the South American context.» British Journal of Social Psychology 56, no. 3: 578-598.

Calcagno, Jorge L. 2013. La construcción de la democracia: Raúl Alfonsín y los militares. Buenos Aires: Corregidor. 
Canelo, Paula. 2010. «La convicción y la responsabilidad: La interna militar en torno a las 'autocríticas' del general Balza durante los años noventa en la Argentina.» VI Jornadas de Sociología de la UNLP, December 9 and 10 2010, La Plata, Argentina.

CONADEP. 1984. Comisión Nacional sobre la Desaparición de Personas. Informe Nunca Más. Buenos Aires: EUDEBA.

Crenzel, Emilio. 2010. «Políticas de la memoria. La historia del informe Nunca Más.» Papeles del CEIC 61, no. 2: 1-31.

Drožđek, Boris. 2010. «How do we salve our wounds? Intercultural perspectives on individual and collective strategies of making peace with own past.» Traumatology 16, no. 4: 5-16. doi: 10.1177/1534765610362800

Echebarria, Agustín, \& Darío Páez. 1989. Emociones: perspectivas psicosociales. Madrid: Fundamentos.

Etxebarría, Itziar, Darío Páez, José Valencia, María A. Bilbao, \& Elena Zubieta. 2010. «Efectos de rituales de expiación y glorificación de la Iglesia sobre la guerra civil española.» Revista de Psicología 28, no. 1: 37-80.

Gabisirege, Simon, \& Stella Babalola. 2001. Perceptions about the Gacaca Law in Rwanda: Evidence from a multi-method study. Baltimore: Johns Hopkins University School of Public Health, Center for Communication Programs.

Gibson, James L. 2004. Overcoming Apartheid: Can truth reconcile a divided Nation? New York: Russell Sage Foundation.

Greiff, Pablo de. 2008. "Justicia y Reparaciones.» In Reparaciones para las víctimas de violencia política: estudios de caso y análisis comparado, edited by Catalina Díaz, 407-440. Bogotá: ICTJ.

Greiff, Pablo de. 2011. "Algunas reflexiones acerca del desarrollo de la Justicia Transicional.» Anuario de Derechos Humanos 7: 17-39. doi:10.5354/07182279.2011.16994

Greiff, Pablo de. 2012. «Teorizar la justicia transicional.» American Society for Political and Legal Philosophy 51: 31-77.

Greiff, Pablo de. 2014. «Transitional Justice and development.» In International Development: Ideas, Experience, and Prospects, edited by Bruce CurrieAdler, Ravi Kanbur, David M. Malone, \& Rohinton Medhora, 412-427. Oxford: Oxford University Press.

Hayner, Priscilla. 1994. "Fifteen Truth Commissions-1974 to 1994: A comparative study.» Human Rights Quarterly 16, no. 4: 597-655.

James, Matt. 2008. «Wrestling with the past: Apologies, quasi-apologies, and non-apologies in Canada.» In The age of apology: Facing up to the past, edited by Mark Gibney, Rhoda E. Howard-Hassmann, Jean-Marc Coicaud, \& Niklaus Steiner, 137-153. Philadelphia: University of Pennsylvania Press.

Janoff-Bulman, Ronnie. 1992. Shattered assumptions: towards a new psychology of trauma. New York: Free Press.

Lira, Elizabeth, \& María I. Castillo. 1991. Psicología de la amenaza política y del miedo. Santiago de Chile: CERSOC.

Lundy, Patricia, \& Mark McGovern. 2008. «Whose justice? Rethinking transitional justice from the bottom up.» Journal of Law and Society 35, no. 2: 265-292. 
Manzi, Jorge, \& Roberto González. 2007. «Forgiveness and reparation in Chile: The role of cognitive and emotional intergroup antecedents.» Peace and Conflict 13, no. 1: 71-91.

Martín-Baró, Ignacio. 2003. Poder, ideología y violencia. Madrid: Trotta.

McEvoy, Kieran. (2007). "Beyond Legalism: Towards a thicker understanding of transitional justice.» Journal of Law and Society 34, no. 4: 411-440.

Muratori, Marcela, \& Elena Zubieta. 2013. "Miedo al delito y victimización como factores influyentes en la percepción del contexto social y clima emocional.» Boletín de Psicología, 109: 7-18.

Páez, Darío. 2010. "Official or political apologies and improvement of intergroup relations: a neo-Durkheimian approach to official apologies as rituals.» Revista de Psicología Social 25, no. 1: 101-115.

Páez, Darío, Nekane Basabe, \& José L. González. 1997. «Social processes and collective memory: A cross-cultural approach to remembering political events.» In Collective memory of political events: Social psychological perspectives, edited by James W. Pennebaker, Darío Páez, \& Bernard Rimé, 147-174. Hillsdale, NJ: Lawrence Erlbaum.

Páez, Darío, \& James Liu. 2011. "Collective Memory of Conflicts.»In Intergroup conflicts and their resolution: Social Psychological Perspective, edited by Daniel Bar-Tal, 105-124. New York: Psychology Press.

Reyes, Carlos, Gino Grondona, \& Marcelo Rodríguez. 2015. «Evaluación del impacto de la Comisión de la Verdad en Ecuador: aportes psicosociales en la actual discusión sobre la reparación a las víctimas.» Psicología Política 15, no. 32: 119-136.

Rivera, Joseph de. 1992. "Emotional climate: Social structure and emotional dynamics.» International Review of Studies on Emotion 2: 197-218.

Rivera, Joseph de. 2014. "Culturas de Paz y el clima emocional en las sociedades.» In Psicología social y política: procesos teóricos y estudios aplicados, edited by Elena Zubieta, José F. Valencia, \& Gisela Delfino, 159178. Buenos Aires: Eudeba.

Robben, Antonius C. 2005. "How traumatized societies remember: The aftermath of Argentina's dirty war.» Cultural Critique 59, no. 1: 120-164.

Salvi, Valentina. 2012. De vencedores a víctimas: memorias militares sobre el pasado reciente en la Argentina. Buenos Aires: Biblos.

Salvi, Valentina. 2015. "Guerra, subversivos y muertos. Un estudio sobre las declaraciones de militares en el primer año de democracia.» In Democracia, hora cero. Actores, políticas y debates en los inicios de la postdictadura, edited by Claudia Feld, \& Marina Franco, 153-193. Buenos Aires: Fondo de Cultura Económica.

Schey, Peter, Shelton, Dinah, \& Naomi Roth-Arriaza. 1997. "Addressing Human Rights Abuses: Truth Commissions and the Value of Amnesty.» Whittier Law Review 19: 325-344.

Stein, Dan J., Soraya Seedat, Debra Kaminer, Hashim Moomal, Allen Herman, John Sonnega, \& David R. Williams. 2008. "The impact of the Truth and Reconciliation Commission on psychological distress and forgiveness in 
South Africa.» Social Psychiatry and Psychiatric Epidemiology 43: 462-468. doi: 10.1007/s00127-008-0350-0

United Nations (2004). Reporte del SecretarioGeneral, el Estado de Derecho y la Justicia Transicional en las sociedades en conflicto y postconflicto. August 3rd 2004, UN Doc S/2004/616.

Zubieta, Elena, Juan I. Bombelli, \& Marcela Muratori. 2015. «Argentina: el impacto de la implementación de medidas de Justicia Transicional post Dictadura.» Psicología Política 15, no. 32: 101-118.

Zubieta, Elena, Gisela Delfino, \& Omar Fernández. 2008. "Clima social emocional, confianza en las instituciones y percepción de problemas sociales. Un estudio con estudiantes universitarios urbanos argentinos.» Psykhe 17, no. 1: 5-16. 


\section{Copyright}

Deusto Journal of Human Rights / Revista Deusto de Derechos Humanos is an Open Access journal; which means that it is free for full and immediate access, reading, search, download, distribution, and reuse in any medium only for non-commercial purposes and in accordance with any applicable copyright legislation, without prior permission from the copyright holder (University of Deusto) or the author; provided the original work and publication source are properly cited (Issue number, year, pages and DOI if applicable) and any changes to the original are clearly indicated. Any other use of its content in any medium or format, now known or developed in the future, requires prior written permission of the copyright holder.

\section{Derechos de autoría}

Deusto Journal of Human Rights / Revista Deusto de Derechos Humanos es una revista de Acceso Abierto; lo que significa que es de libre acceso en su integridad inmediatamente después de la publicación de cada número. Se permite su lectura, la búsqueda, descarga, distribución y reutilización en cualquier tipo de soporte sólo para fines no comerciales y según lo previsto por la ley; sin la previa autorización de la Editorial (Universidad de Deusto) o la persona autora, siempre que la obra original sea debidamente citada (número, año, páginas y DOI si procede) y cualquier cambio en el original esté claramente indicado. Cualquier otro uso de su contenido en cualquier medio o formato, ahora conocido o desarrollado en el futuro, requiere el permiso previo por escrito de la persona titular de los derechos de autoría. 